\title{
Estrogen receptor- $\alpha$ mediates estrogen-inducible abnormalities in the developing penis
}

\author{
H O Goyal ${ }^{1}$, T D Braden ${ }^{3}$, P S Cooke ${ }^{4}$, M A Szewczykowski ${ }^{4}$, C S Williams ${ }^{1}$, P Dalvi $^{1}$ \\ and J W Williams ${ }^{2}$ \\ Departments of ${ }^{1}$ Biomedical Sciences and ${ }^{2}$ Biology and CBR/RCMI, Tuskegee University, Tuskegee, Alabama 36088, \\ USA, ${ }^{3}$ Department of Anatomy, Physiology and Pharmacology, Auburn University, Auburn, Alabama, USA and \\ ${ }^{4}$ Department of Veterinary Biosciences, University of Illinois, Urbana, Illinois, USA
}

Correspondence should be addressed to H O Goyal who is now at Department of Biomedical Science, College of Veterinary Medicine, Nursing and Allied Health, Tuskegee University, Tuskegee, Alabama 36088, USA; Email: goyalho@tuskegee.edu

\begin{abstract}
Previously, we reported an association between estrogen receptor- $\alpha(E R \alpha)$ upregulation and detrimental effects of neonatal diethylstilbestrol (DES) exposure in the rat penis. The objective of this study was to employ the ER $\alpha$ knockout (ER $\alpha \mathrm{KO}$ ) mouse model to test the hypothesis that ER $\alpha$ mediates DES effects in the developing penis. ER $\alpha$ KO and wild-type C57BL/6 mice received oil or DES at a dose of $0.2 \mu \mathrm{g} / \mathrm{pup}$ per day $(0.1 \mathrm{mg} / \mathrm{kg})$ on alternate days from postnatal days 2 to 12. Fertility was tested at 80 240 days of age and tissues were examined at 96-255 days of age. DES caused malformation of the os penis, significant reductions in penile length, diameter, and weight, accumulation of fat cells in the corpora cavernosa penis, and significant reductions in weight of the bulbospongiosus and levator ani muscles in wild-type mice. Conversely, ERaKO mice treated with DES developed none of the above abnormalities. While nine out of ten male mice sired pups in the wild-type/control group, none did in the wildtype/DES group. ER $\alpha \mathrm{KO}$ mice, despite normal penile development, are inherently infertile. Both plasma and intratesticular testosterone levels were unaltered in the DES-treated wild-type or DES-treated ER $\alpha \mathrm{KO}$ mice when compared with controls, although testosterone concentration was much higher in the ER $\alpha$ KO mice. Hence, the resistance of ER $\alpha$ KO mice to developing penile abnormalities provides unequivocal evidence of an obligatory role for ER $\alpha$ in mediating the harmful effects of neonatal DES exposure in the developing penis.

Reproduction (2007) 133 1057-1067
\end{abstract}

\section{Introduction}

It is well known that androgens are critical in development of male reproductive organs in all mammals studied to date (George \& Wilson 1994). It is also known that dihydrotestosterone, a $5 \alpha$-reductase reduced testosterone metabolite, is more critical than testosterone in development of those organs which are derived from the urogenital sinus, genital tubercle, and genital swelling in males, including the penis (Anderson \& Clark 1990, George \& Wilson 1994). Notably, the early differentiation and morphogenesis of male reproductive organs corresponds to the testosterone surge by fetal Leydig cells that occurs at about 12 weeks of gestation in humans (Williams-Ashman \& Reddi 1991, George \& Wilson 1994, Klonisch et al. 2004) and at late gestation and early neonatal period in rodents (Ward \& Weisz 1984, El-Gehani et al. 1998). Alterations in androgenic activity during the critical period of differentiation, resulting from abnormalities in testosterone,
$5 \alpha$-reductase, or androgen receptor, cause maldevelopment of internal and external male genitalia, including hypospadias and shorter penis (Gray et al. 2001, Sultan et al. 2001, Kim et al. 2002, Foster \& Harris 2005). In a situation where androgen receptors are inherently lacking, such as in androgen insensitivity syndrome, external genitalia develop as those of females (Wiener et al. 1997, Regadera et al. 1999, Hiort 2000).

Unlike the case with androgens, the role of estrogen in development of male reproductive organs, especially in the penis, remains largely unknown; although both estrogen receptors (ERs) and/or aromatase enzyme have been localized in the developing penis of a number of species, including humans (Crescioli et al. 2003, Schultheiss et al. 2003, Dietrich et al. 2004) and rodents (Jesmin et al. 2002, 2004), and rabbits (Srilatha \& Adaikan 2004). Additionally, epidemiological studies have suggested links between inappropriate estrogen exposure and higher frequency of reproductive 
abnormalities in men and wild animals (Toppari et al. 1996, McLachlan et al. 2001, Safe et al. 2001, Mosconi et al. 2002, Fisher 2004, Vidaeff \& Sever 2005, Storgaard et al. 2006, reviews). In this context, it is noteworthy that male offspring of women exposed to diethylstilbestrol (DES) during pregnancy have higher incidence of epididymal cysts, cryptorchidism, hypospadias, and smaller penis (Gill et al. 1979, Swan 2000, Klip et al. 2002), as well as higher incidence of hypospadias in sons of women exposed to DES in fetus, implying a transgenerational effect (Klip et al. 2002, Brouwers et al. 2006); pregnant mothers with high intake of phytoestrogens as a result of vegetarian diet are more likely to give birth to boys with hypospadias (North \& Golding 2000); laboratory animals exposed neonatally to estrogen develop hypospadias (McLachlan et al. 1975, Kim et al. 2004, Newbold 2004); neonatal exposure to estrogen at low doses enlarges the adult prostate gland, while higher doses have the opposite effect (vom Saal et al. 1997, Gupta 2000, Putz et al. 2001, vom Saal \& Hughes 2005); and perinatal estrogen exposure predisposes the prostate gland to a precancerous growth at adulthood by an epigenetic mechanism (Ho et al. 2006). Hence, prenatal and/or neonatal exposure to estrogens can have permanent, and even transgenerational, deleterious effects on the development of male reproductive organs; however, the mechanism underlying estrogen-inducible abnormal phenotypes in the male reproductive tract, as well as in the penis, remains unknown.

Recently, we reported permanent dysmorphogenesis of the penis and loss of fertility in adult rats-treated neonatally with DES or estradiol valerate (Goyal et al. 2004a,b, $2005 a, b)$. Specifically, these studies showed significant reductions in penile length and weight, maldevelopment of the os penis, and accumulation of fat cells and loss of cavernous spaces and smooth muscle cells in the body of the penis. Furthermore induction of these novel phenotypes is dose-dependent, requires a critical window of exposure, and is associated with decreased plasma testosterone and upregulation of ER $\alpha$ expression in the body of the penis. These observations lead us to hypothesize that a functional $E R \alpha$-mediated pathway is required in induction of aberrant penile development.

Hence, the objective of this study is to test the above hypothesis by treating $E R \alpha$ knockout (ER $\alpha K O)$ mice neonatally with DES because they inherently lack ER $\alpha$ and, therefore, should be resistant to DES-inducible penile abnormalities, which should develop in the wildtype mice treated similarly.

\section{Materials and Methods}

\section{Animals and treatments}

Heterozygous breeding pairs for the ER $\alpha$ null allele were crossed to generate $\mathrm{ER} \alpha \mathrm{KO}$ and wild-type $\mathrm{C} 57 \mathrm{BL} / 6$ mice in a continuous breeding scheme at the University of Illinois at Urbana- Champaign. Pups were treated with DES at a dose of $200 \mathrm{ng}(0.1 \mathrm{mg} / \mathrm{kg})$ in $25 \mu \mathrm{l}$ olive oil, per pup, every other day, from postnatal days 2 to 12 (note, the same dose regimen was used in our previous studies in the rat, Goyal et al. 2004a,b). Controls received olive oil only. DNA was isolated between 8 and 12 days of age, from tail tissues using DirectPCR Lysis Reagent (Viagen Biotech Inc., Los Angeles, CA, USA) and used to determine genotype. Animals were shipped to Tuskegee University at adulthood for further study. Animals at both universities were maintained at $22-23{ }^{\circ} \mathrm{C}$ ambient temperature, $55-60 \%$ relative humidity, and $12 \mathrm{~h}$ light:12 h darkness cycle, and had free access to food (Rodent Chow 5001; Purina Mills, St.Louis, MO, USA) and water for $24 \mathrm{~h}$. Animals were handled in accordance with the guidelines for the Care and Use of Laboratory Animals (Institute of Laboratory Animal Resources, National Research Council, National Academy Press, Washington, DC, 1996). All animal procedures were approved by the Institutional Animal Care and Use Committees of the University of Illinois at UrbanaChampaign and Tuskegee University.

\section{Body and organ weights}

All animals were weighed and terminated at 96-255 days of age. The seminal vesicles were weighed as a marker for DES effects on the accessory gland because estrogens are known to have an inhibitory effect on this gland (Goyal et al. 2003, 2004a,b). The testes and epididymides were also weighed, but the data are not included in the study because the weight of both organs in the wild-type/DES mice and that of the testes in the $\mathrm{ER} \alpha \mathrm{KO} / \mathrm{oil}$ or $\mathrm{ER} \alpha \mathrm{KO} / \mathrm{DES}$ mice varied widely among animals. These variations resulted from retention of the testis and epididymis of one or both sides in the inguinal canal in more than $70 \%$ of the wild-type/DES mice and from accumulation of the testicular fluid in the testis of one or both sides of the ERaKO mice, which worsened with age.

\section{Penis and penile skeletal muscles}

The penis was measured for length, diameter, and weight and was processed as described previously (Goyal et al. $2005 a, b)$. Briefly, the penis was exposed up to the ischial arch, and its stretched length was measured from the tip of the glans penis to the midpoint of the ischial arch, and the diameter was measured from the middle of the body of the penis. After removing the free loose connective tissue, the entire penis was weighed. Two to three millimeter long sections from the middle of the body were processed for histopathology and histochemistry ( $n \geq 5$ per group). For histopatholgy, tissues were fixed in formaldehyde, and $5 \mu \mathrm{m}$ thick paraffin sections were 
stained with hematoxylin and eosin (H\&E) for general morphology and with Masson's Trichrome stain for smooth muscle. For histochemical demonstration of fat, formaldehyde-fixed tissues were en block stained for $8 \mathrm{~h}$ with $1 \%$ osmium tetroxide dissolved in $2.5 \%$ potassium dichromate solution, and then processed for paraffin embedding. In addition, epoxy sections ( $1 \mu \mathrm{m}$ thick) of glutaraldehyde-fixed tissues were stained with toluidine blue. For evaluating the development of os penis, 1 penis from each group was radiographed with a cabinet radiograph system (Faxitron series, Hewlett-Packard) as described previously (Goyal et al. 2004b).

The rodent penis is surrounded by three pairs of skeletal muscles: ischiocavernosus extends from the ischial arch to the middle of the dorsal surface of the body of the penis; bulbospongiosus surrounds the ventro-lateral surface of the bulb of the penis; and levator ani forms a sling-like band around the anus and is connected dorsally to the bulbospongiosus. The latter two muscles were isolated, freed from connective tissue and fat, and weighed separately.

Digital images of paraffin and epoxy sections, as well as of the radiograph, were captured with a Leitz Orthoplan microscope (Vashaw Scientific Inc., Norcross, GA, USA) and the Kodak Microscopy Documentation System 290 (Eastman Kodak Company), and were assembled with the use of Adobe Photoshop 7.0.

\section{Plasma and intratesticular testosterone}

For plasma testosterone, one blood sample was collected by cardiac puncture from each animal just prior to necropsy; and for intratesticular testosterone, a part of the right testis was collected from each animal at the time of necropsy. Both plasma and testicular parenchyma were frozen at $-20^{\circ} \mathrm{C}$ until assayed. Testes were processed in accordance with the protocol described by Park et al. (2002). Briefly, $50 \mathrm{mg}$ testicular tissue was homogenized in PBS. Eight volumes of ether were added to the homogenate and vortexed vigorously. The aqueous phase was snap-frozen, and the organic supernatant was transferred to a secondary tube and air dried. Just prior to assay, samples were resuspended in PBS. Testosterone in plasma and testicular tissue was measured using a COAT-A-COUNT testosterone RIA (Diagnostic Products Corporation, Los Angeles, CA, USA) according to manufacturer's protocol. The sensitivity of the assay was $0.2 \mathrm{ng} / \mathrm{ml}$. The intra- and interassay coefficients of variations were 6 and $12 \%$ respectively.

\section{Fertility}

Eight to ten adult male mice from each group were transferred to mating cages and cohabited with untreated, 70- to 80-day-old females (1:2) for 12 days. At the end of cohabitation, females were separated and allowed to deliver at term. The number of pups was recorded for each litter.

\section{Statistical analysis}

Statistical analyses were performed using Sigma Stat statistical software (Jandel Scientific, Chicago, IL, USA). Two-way ANOVA was performed on all parameters. Treatment groups with means significantly different $(P<0.05)$ from controls were identified using the Student-Newman-Keuls (SNK) test. When data were not distributed normally, or heterogeneity of variance was identified, analyses were performed on transformed data or ranked data.

\section{Results}

\section{Body and organ weights}

The mean body weight in the adult wild-type and ER $\alpha K O$ control mice was 25.88 and 26.53 g respectively, and was not altered as a result of DES treatment (25.68 vs $26.82 \mathrm{~g}$ ). Seminal vesicles were weighed as a marker for DES effects in the male accessory sex organs. Their weight was reduced by almost $70 \%$ in the wild-type/DES mice when compared with that of wild-type controls, but was not significantly $(P<0.05)$ different between the ER $\alpha$ KO/DES and ER $\alpha K O /$ control mice (Fig. 1). Generally, seminal vesicles were one, one and half or two times heavier in the ERaKO mice than in the wild-type/control mice.

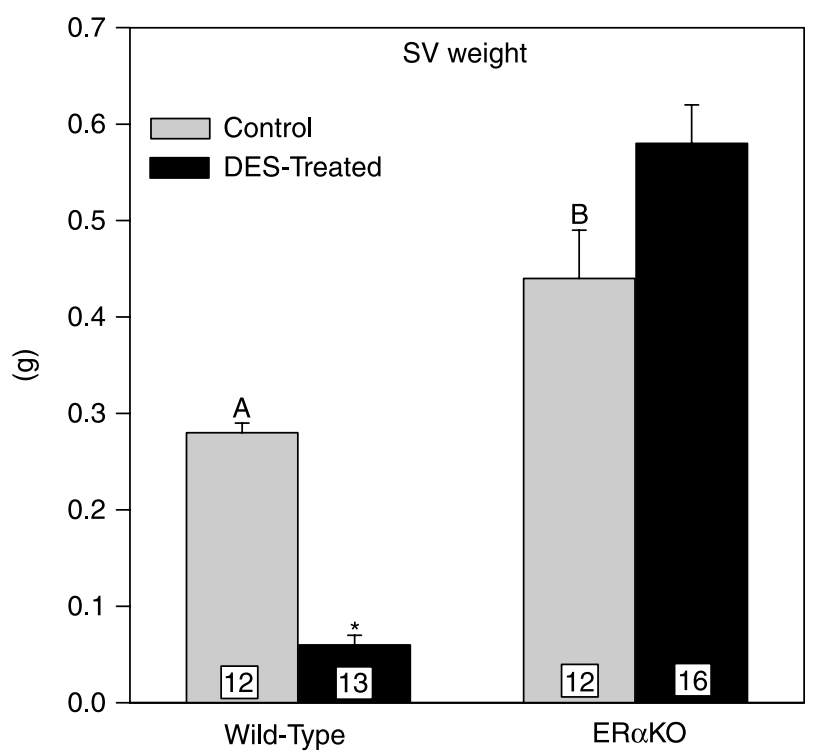

Figure 1 The paired weight of the seminal vesicles (SV) in wild-type and ER $\alpha$ KO adult mice treated neonatally with oil (control) or DES. An asterisk indicates a significant $(P \leq 0.05)$ reduction in weight in the wild-type mice, as a result of DES treatment. Bars with different superscripts indicate significantly higher weight in the ERaKO/control mice than in the wild-type/control mice $((P \leq 0.05)$. Data are expressed as mean \pm S.E.M. 


\section{Penile measurements}

The mean measurements of the penis, including weight, length, and diameter, were significantly $(P<0.05)$ lower in wild-type/DES mice when compared with those of wild-type/control mice (Fig. 2); and the decrease was more pronounced for weight than length ( $56 \%$ vs $25 \%$ ). Conversely, DES exposure failed to exhibit any of the above detrimental effects in the penis of ER $\alpha \mathrm{KO}$ mice. All penile measurements in the ERaKO/DES or ERaKO/ control mice were similar to those in the wild-type/ control mice.

\section{Penile skeletal muscles}

The weight of both bulbospongiosus and levator ani muscles was significantly $(P<0.05)$ lower in the wildtype/DES mice when compared with that of the wildtype/control mice (Fig. 3), although the percent reduction was much higher for the former muscle $(68 \%$ vs $35 \%)$. In contrast, DES failed to affect the weight of either muscle in the ER $\alpha$ KO mice. The weight
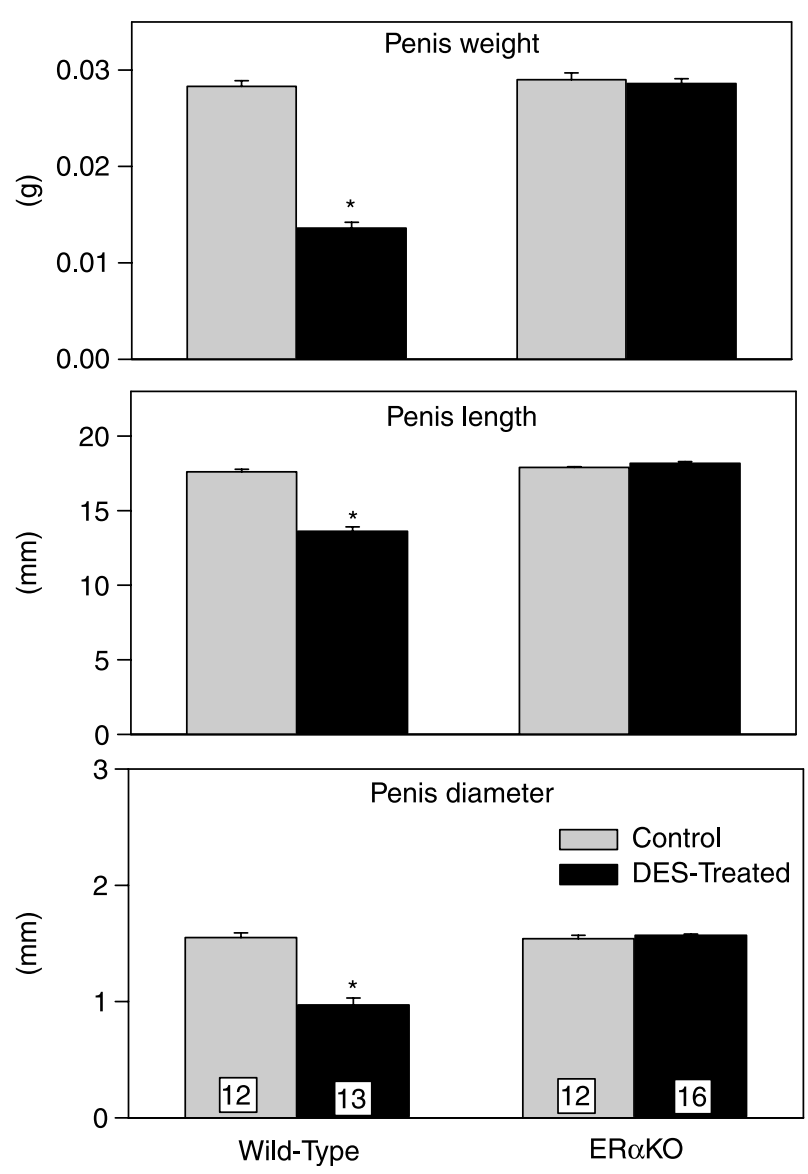

Figure 2 The weight, length, and diameter of the penis in wild-type and ER $\alpha$ KO adult mice treated neonatally with oil (control) or DES.

*Significantly $(P \leq 0.05)$ different from controls. Data are expressed as mean \pm S.E.M.
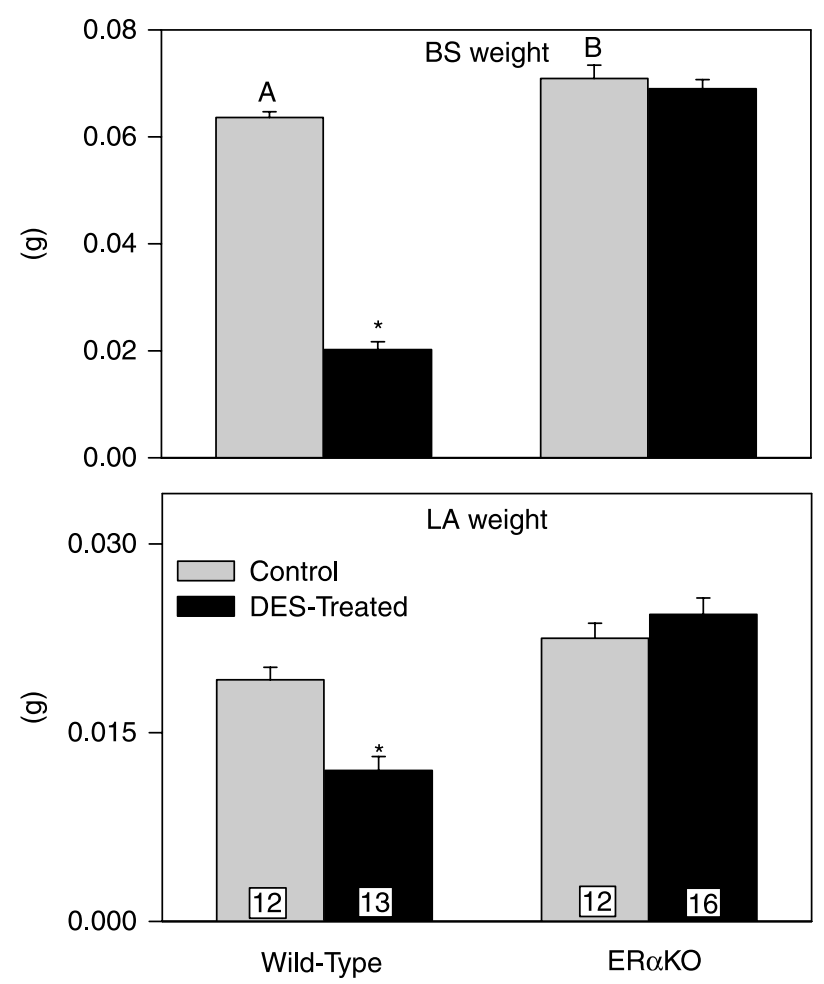

Figure 3 The paired weight of the bulbospongiosus (BS) and levator ani muscles in wild-type and ER $\alpha \mathrm{KO}$ adult mice treated neonatally with oil (control) or DES. *Significantly $(P \leq 0.05)$ different from controls. Bars with different superscripts are significantly different $(P \leq 0.05)$. Data are expressed as mean \pm s.E.M.

of both muscles was almost $10 \%$ higher in both the $\mathrm{ER} \alpha \mathrm{KO} / \mathrm{DES}$ and $\mathrm{ER} \alpha \mathrm{KO} / \mathrm{control}$ mice than in the wildtype/control mice; however, the increase was significant $(P<0.05)$ only in the case of the bulbospongiosus muscle.

\section{Penile gross morphology, histopathology, and histochemistry}

\section{Gross morphology}

The mouse penis, similar to the rat penis (Goyal et al. 2004a), consists of a root, a cylindrical body, and a bulbous glans penis. An os penis extends from the distal end of the body to the tip of the glans penis and is responsible for the right angle bend between the body and the glans penis in a non-erect penis (Fig. 4). Based on gross and radiographic examinations, striking effects of neonatal DES exposure in the wild-type mice included a reduction in the right angle and malformations of the os penis, including its underdevelopment and less calcification. Conversely, these effects were completely lacking in the penis of DES-treated ERaKO mice, which was morphologically similar to that of the $\mathrm{ER} \alpha \mathrm{KO} / \mathrm{control}$ and wild-type/control mice (Fig. 4). 


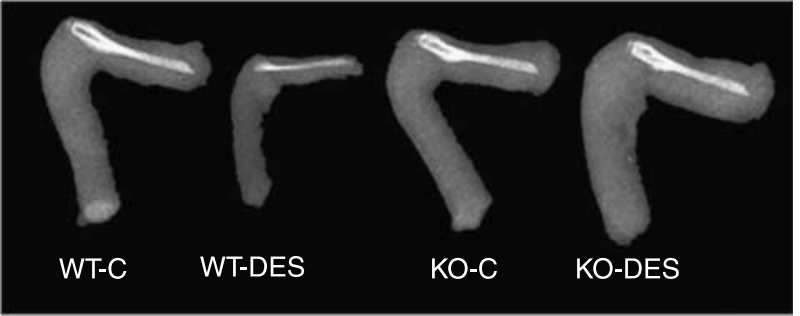

Figure 4 Radiographs of the penis in wild-type control (WT-C), wildtype DES (WT-DES), knockout control (KO-C) and knockout DES (KODES) adult mice treated neonatally with oil (control) or DES. Note abnormal morphology of the penis, including underdevelopment and undercalcification of the os penis, in DES-treated wild-type mice only.

\section{Histopathology and histochemistry}

The body of the penis in both wild-type and ERaKO mice consists of three erectile bodies: two corpora cavernosa that are located dorso-lateral to the urethra and are partly separated by an intercrural septum that brings blood vessels and nerves to the crura and a corpus spongiosus that is located ventrally and surrounds the urethra (Fig. 5A-D). The corpora cavernosa contain endothelial-lined cavernous spaces (also called sinusoids), thin strands of smooth muscle cells surrounding the endothelium, and connective tissue trabeculae between cavernous spaces. In addition, a thick tunica albuginea capsule, consisting of an outer fibrous layer and an inner cellular layer, surrounds the corpora cavernosa.

An examination of paraffin sections stained with hematoxylin and eosin or Masson's Trichrome (distinguishes smooth muscle cells from collagen fibers) revealed that, among various histological components of the penis, the tunica albuginea capsule and connective tissue trabeculae were less developed in the DES-treated wild-type mice when compared with those of the wild-type/control mice (Fig. 6A and B). In addition, an examination of epoxy sections stained with toluidine blue (Fig. 6C and D) and of undeparaffinized sections stained with osmium tetroxide (Fig. 7A-D) showed an abnormal accumulation of fat cells in the DES-treated wild-type mice. Again, none of the above histopathological abnormalities resulted in the penis of DES-treated ER $\alpha$ KO mice, which was structurally similar to that of the wild-type/control or the ERaKO/control mice.

\section{Plasma and intratesticular testosterone}

Neonatal DES exposure did not significantly $(P<0.05)$ alter the mean concentration of plasma or intratesticular testosterone in the wild-type or the ER $\alpha$ KO mice at adulthood (Fig. 8); however, both concentrations were almost three- to four-fold higher in the DES- or oil-treated ER $\alpha \mathrm{KO}$ mice than in the wild-type/control mice.

\section{Fertility}

While nine out of ten males in the wild-type/control group sired pups, with a mean litter size of 6.5 pups (ranging from 4 to $11 \mathrm{pups} / \mathrm{l}$ ), no male sired a pup in the DES-treated wild-type group or ERaKO groups treated with oil or DES ( $n=8 /$ group).

\section{Discussion}

The objective of this study was to test the hypothesis that $E R \alpha$ is essential in mediating detrimental effects of
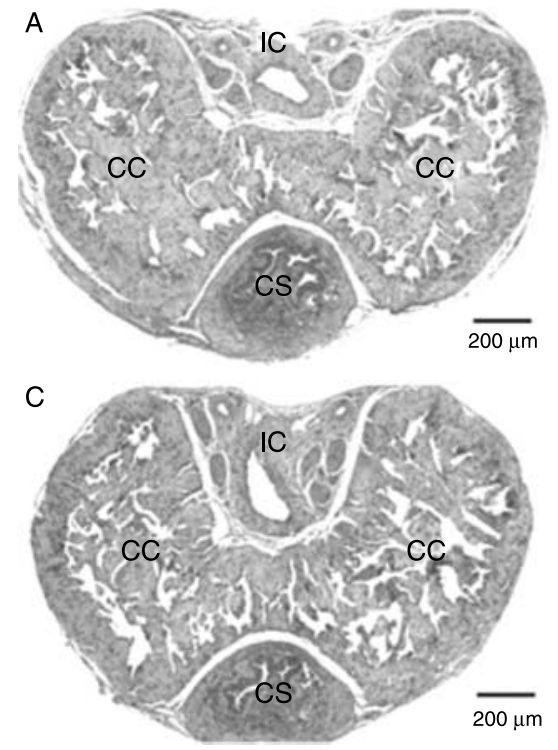

www.reproduction-online.org
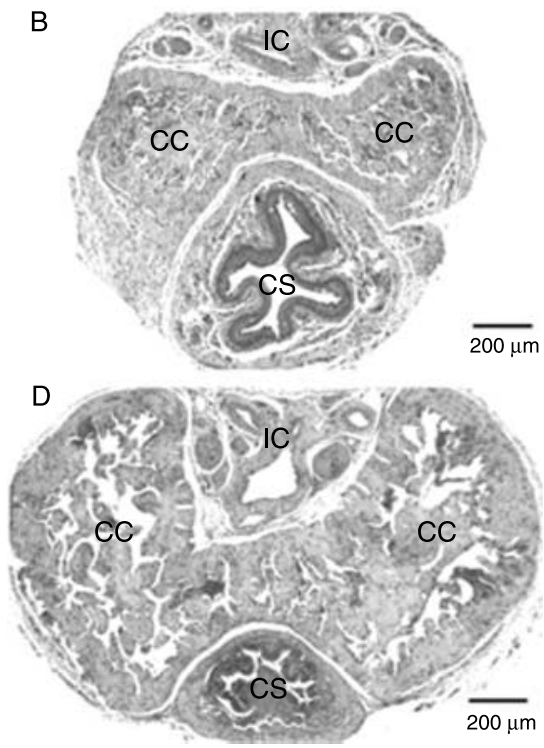

Figure 5 Micrographs of the body of the penis in wild-type (A and $B$ ) and $E R \alpha K O(C$ and $D)$ adult mice treated neonatally with oil ( $A$ and $C$ ) or DES ( $B$ and $D)$. Note, different parts of the body of the penis, including a paired corpora cavernosa (CC), a corpus spongiosus (CS), and an intercrural septum (IC) containing blood vessels and nerves are morphologically developed in both the wild-type and ER $\alpha$ KO mice, regardless whether they are treated with oil or DES. However, the corpora cavernosa in the case of the wild-type DES group only is dramatically reduced in size. Hematoxylin and eosin. 

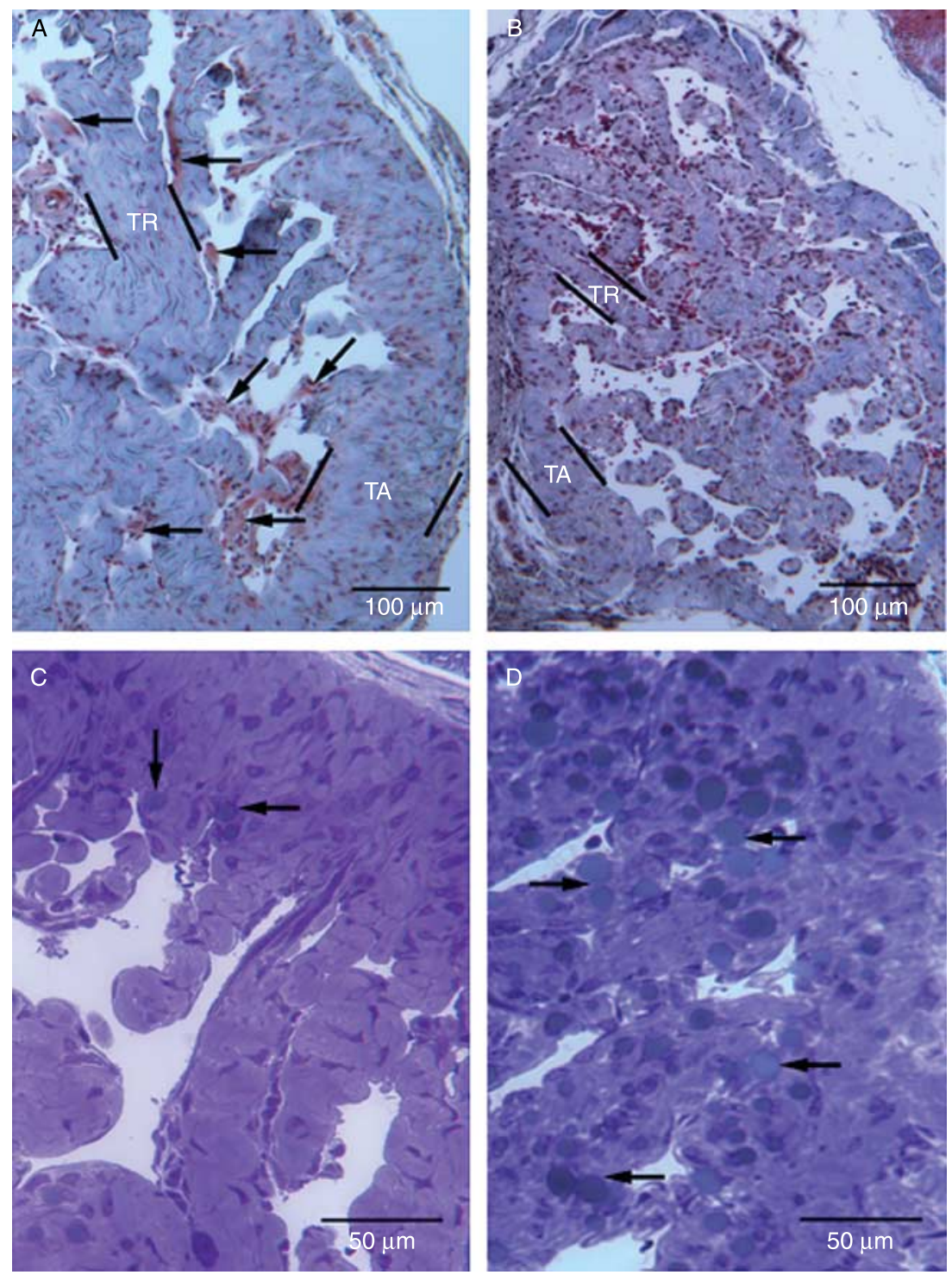

Figure 6 Micrographs of the body of the penis in wild-type adult mice treated neonatally with oil (A and $\mathrm{C}$ ) or DES (B and D). (A and B) In these micrographs, note a significant reduction in thickness of the tunica albuginea (TA) surrounding the corpora cavernosa and the trabeculae (TR) separating cavernous spaces, as a result of DES treatment. In addition, arrows indicate brownishstained smooth muscle cells in the trabeculae, which were mainly seen in control mice. (C and D) In these micrographs, arrows indicate fat droplets, which are aggregated in large numbers in DEStreated mice, in contrast to only a few in control mice. (A and B), Masson's Trichrome; (C and D), toluidine blue. neonatal estrogen exposure in the developing penis. To test this hypothesis, we employed the ERaKO mouse model because it lacks ER $\alpha$ genetically. We reasoned that if $\mathrm{ER} \alpha$ expression is obligatory then $\mathrm{ER} \alpha \mathrm{KO}$ mice should be resistant to the harmful effects of neonatal DES exposure. Results of the present study showed for the first time that ER $\alpha \mathrm{KO}$ males were completely resistant to the harmful effects of neonatal DES exposure, which were consistently observed in the penis of wild-type C57BL/6 mice, providing unequivocal evidence of an obligatory role for $\mathrm{ER} \alpha$ in mediating estrogen-inducible abnormalities in the developing penis.

The penis is not the only reproductive organ in which the presence of ER $\alpha$ is crucial for estrogeninducible developmental deformities. The prostate gland in the ERaKO males treated neonatally with DES on postnatal days 1, 3, and 5 and examined at different ages up to 18 months of age were normal in all age groups, while that of the wild-type mice treated similarly developed alterations at the cellular and molecular levels, including epithelial hyperplasia and dysplasia, which worsened with age (Prins et al. 2001). Adult ER $\alpha$ KO female mice treated with DES noenatally failed to develop pathological abnormalities that were observed in the uterus, oviduct, and vagina of similarly treated wild-type mice (Couse et al. 2001). On the other hand, mice lacking ER $\beta$ $(E R \beta K O)$ and treated with DES neonatally developed abnormalities in the prostate (Prins et al. 2001) and female genital organs (Couse \& Korach 2004), similar to those observed in the DES-treated wild-type mice. Thus, the above studies, as well as our present study, underscore an essential role of $E R \alpha$ in mediating detrimental effects of neonatal estrogen exposure not only in the penis but also in other reproductive organs of both sexes. 

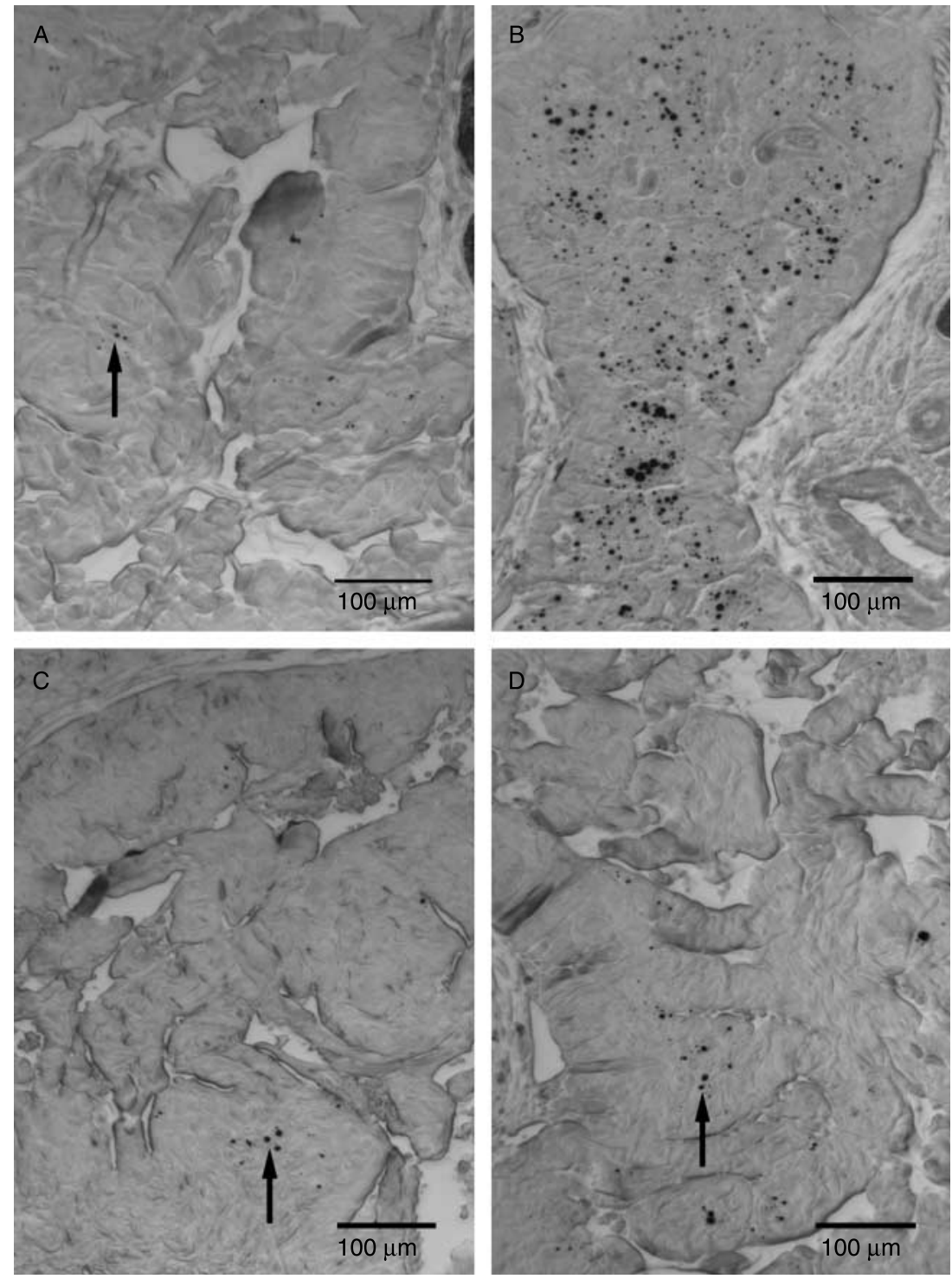

Figure 7 Micrographs of the corpora cavernosa penis in wild-type $(\mathrm{A}$ and $\mathrm{B})$ and $\mathrm{ER} \alpha \mathrm{KO}(\mathrm{C}$ and $\mathrm{D})$ adult mice treated neonatally with oil (A and $C$ ) or DES (B and D). Note accumulation of fat cells in wild-type DES mice, in contrast to a few, isolated fat cells (arrows) in all other groups. Fat stain, undeparaffinized sections stained en block with osmium tetroxide.
Similarities in penile abnormalities presently observed in DES-treated wild-type mice with those previously reported from our laboratory in DES-treated rats (Goyal et al. 2005a,b), including malformations of the os penis; reductions in weight, length, and diameter of the penis; reductions in thickness of the tunica albuginea capsule and connective tissue trabeculae in the corpora cavernosa penis; and abnormal accumulation of fat cells in the corpora cavernosa penis; clearly identify the penis as a target organ for harmful effects of neonatal estrogen exposure. Similarly, other studies also reported a smaller penis in laboratory animals exposed neonatally to estrogen (McLachlan et al. 1975, Zadina et al. 1979, Newbold 2004); and the rabbit penis treated with bisphenol A (Moon et al. 2001) or tetrachlorodibenzodioxin (Moon et al. 2004) had subtunical deposition of fat in the corpora cavernosa. Additionally, alligators from Lake Apopka, FL, contaminated with environmental pollutants had smaller phalluses (Guillette et al. 1994, 1996, Milnes et al. 2005); and male offspring of women exposed to DES during pregnancy had smaller penises (Gill et al. 1979, Swan 2000).

However, unlike in the DES-treated rat penis, which also showed loss of cavernous spaces (sinusoids) and smooth muscle cells (Goyal et al. 2004a,b, 2005a,b), both structures were present in the corpora cavernosa penis of wild-type mice treated neonatally with DES. Reasons for this difference may be attributed to differences in the species, or to the developmental stage of the penis at the time of estrogen exposure, because, even within the rat, the severity of loss of smooth muscle cells and cavernous spaces and the degree of accumulation of fat cells was higher in the penis exposed to estrogen from postnatal days 1 to 6 than that exposed from postnatal days 7 to 12 

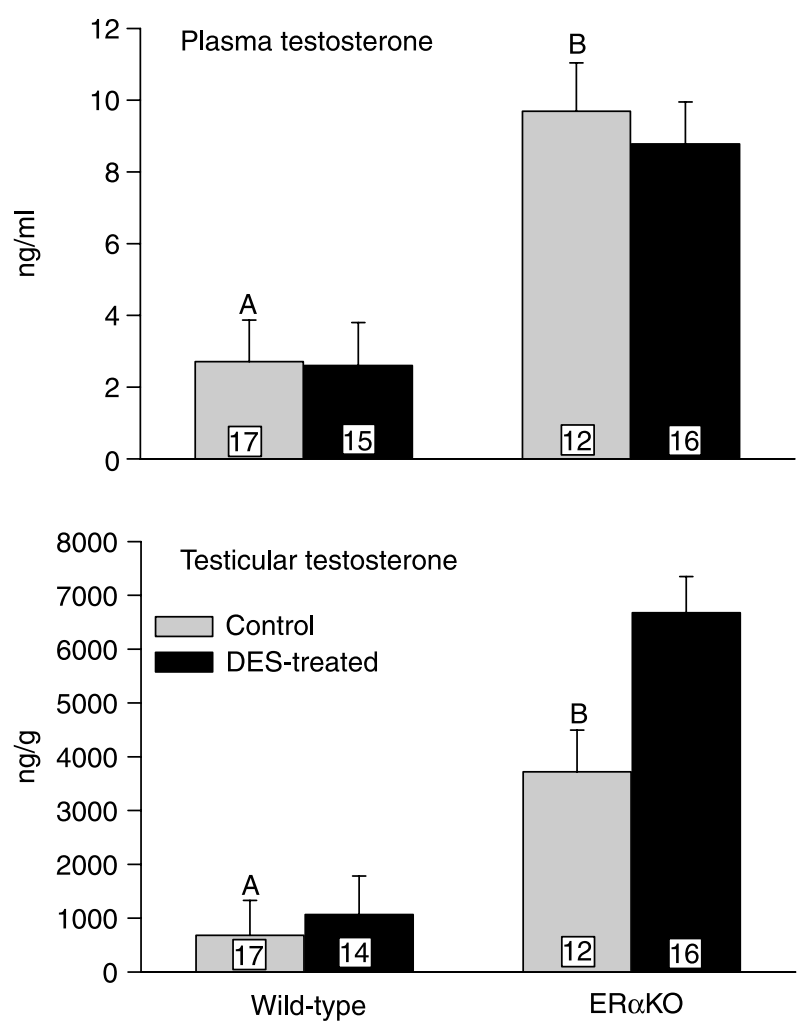

Figure 8 Plasma testosterone and intratesticular testosterone in wildtype and ER $\alpha$ KO adult mice treated neonatally with oil (control) or DES. Bars with different superscripts are significantly different $(P \leq 0.05)$. Data are expressed as mean \pm S.E.M.

(Goyal et al. 2005b). Considering that the length of gestation is shorter in mice than rats (19-21 days vs 21-23 days), it is logical to suggest that stromal cells at birth are at a more advanced stage of differentiation in the mouse penis than the rat penis and thus this difference may be a factor in the differential response observed in the penis of these two species.

An important observation of the present study that the penis of ER $\alpha \mathrm{KO}$ and wild-type control mice is morphologically similar implies that $E R \alpha$ is not required for normal development of the penis. Similarly, reports of fertility in ERßKO (Couse \& Korach 1999) and aromatase knockout (Fisher et al. 1998) male mice indicate that neither ER $\beta$ nor estrogen is essential in normal penile development. This is despite the fact that ER $\alpha$ and $E R \beta$ (Jesmin et al. 2002), as well as aromatase enzyme (Jesmin et al. 2004, Mowa et al. 2006), are present in the neonatal rat penis. Hence, based on the available data, it appears that neither ER $\alpha$ nor ER $\beta$ nor estrogen has a significant role in normal development of the penis. On the contrary, the present data provide unequivocal evidence for a crucial role of $E R \alpha$ in mediating estrogen-driven abnormal development of the penis.

One potential mechanism by which neonatal estrogen exposure induces developmental abnormalities may involve an activation of ER $\alpha$-mediated signaling because we previously found an association between $E R \alpha$ upregulation and penile abnormalities in the developing rat penis treated neonatally with DES (Goyal et al. $2004 b, 2005 b)$. Similarly, ER $\alpha$ upregulation is associated with abnormal development of rodent female reproductive tract (Yamashita et al. 1990, Markey et al. 2005), mammary gland (Tekmal et al. 2005), male reproductive tract (Sato et al. 1994), prostate gland (Prins \& Birch 1997, Prins et al. 2001), and seminal vesicles (Williams et al. 2001). In addition, ER $\alpha$ overexpression is shown to inhibit growth and angiogenic factors in the endometrial carcinoma cell line Ishikawa (Ali et al. 2004); and ER $\alpha$ is the main regulator of estrogenic effect on adipose tissue since an alteration in estrogen/ER signaling during development results in dramatic changes in adipocyte number (Cooke \& Naaz 2004).

Another mechanism of estrogen-inducible, developmental penile abnormalities may involve alterations in androgen action because androgen receptors are ubiquitously present in the rat penis (Goyal et al. $2004 b$ ), and their concentration is maximal prior to puberty (Rajfer et al. 1980, Takane et al. 1990). Additionally, neonatal estrogen exposure downregulates androgen receptor level in male reproductive organs (Prins \& Birch 1995, McKinnell et al. 2001, Williams et al. 2001, Woodham et al. 2003) and lowers plasma testosterone (Sharpe et al. 1998, Atanassova et al. 2000). Testosterone coadministration with estrogen mitigates developmental abnormalities affecting the male reproductive tract (Rivas et al. 2003). In vitro treatment with androgens promotes smooth muscle differentiation and inhibits adipocyte differentiation in C3H 10T1/2 pluripotent mesenchymal cells (Bhasin et al. 2003, Singh et al. 2003), and castration induces subtunical fat deposition and loss of smooth muscle cells in the corpora cavernosa of the rabbit penis (Traish \& Kim 2005, Traish et al. 2005). Taken together, these observations raise the possibility that lower androgen action via estrogen-induced decrease in testosterone or androgen receptor or both as potential mechanisms contributing to penile abnormalities.

Although neonatal DES exposure in the present study did not significantly alter the adult level of plasma or intratesticular testosterone in wild-type mice, the neonatal level of intratesticular testosterone in rat pups treated with DES for 1-3 postnatal days was reduced by 90\% at postnatal days 5-8 (Goyal et al. 2005b), the developmental period when stromal cells start differentiation in the rat penis (Murakami 1986, 1987), thus suggesting a role for estrogen-induced lower androgen action in inducing penile abnormalities by reprogramming stromal cell differentiation. In this context, observations that endogenous estrogens or DES exposure to fetal or neonatal Leydig cells decreased testosterone secretion in wild-type mice, but not in ERaKO mice, implied an ER $\alpha$-mediated inhibitory role of estrogen in testosterone secretion (Delbes et al. 2005). Supporting 
this role and, in agreement with the previous studies (Eddy et al. 1996, Akingbemi et al. 2003), both plasma and intratesticular testosterone levels are much higher in ERaKO mice than in wild-type mice. Hence, it is hypothesized that the perinatal testosterone surge, typical for rodents from late gestation to first week of life, may be a natural mechanism of downregulating $E R \alpha$ expression in penile stromal cells and thereby safeguarding their normal differentiation at a critical time of penile development. In other words, estrogen-induced downregulation of the perinatal testosterone surge results in ER $\alpha$ upregulation in penile stromal cells and, consequently, abnormal development of the penis in the wild-type mice. Alternatively, the lack of effect in the ER $\alpha$ KO mice could be due to the increased testosterone, which provided protection against DES effects in the same way that testosterone administration protected against DES effects in the neonatal rat (Rivas et al. 2003).

In agreement with our previous observations in the rat (Goyal et al. 2005b), the weight of both penile skeletal muscles, bulbospongiosus and levator ani was not only significantly decreased but also was differentially decreased, with the former muscle undergoing a much higher decrease, as a result of neonatal estrogen exposure to wild-type mice. The mechanism of this differential decrease may lie in differences in androgen receptor concentration because both muscles are androgen dependent (Breedlove \& Arnold 1983, Hadi Mansouri et al. 2003) and, interestingly, both muscles are more developed in ER $\alpha$ KO mice than in wild-type/ control mice. Likewise, a dramatic weight reduction observed in the seminal vesicle in the DES-treated wildtype mice is consistent with our previous data in the rat (Goyal et al. 2005a,b), as well as from other laboratories (Atanassova et al. 2000, Putz et al. 2001, Hendry et al. 2006); and a significantly higher weight of the seminal vesicles in ERaKO mice when compared with wild-type/ control mice is also in agreement with previous observations (Eddy et al. 1996, Couse \& Korach 1999), and is probably attributed to higher testosterone levels in these animals.

In conclusion, ER $\alpha \mathrm{KO}$ mice are resistant to estrogeninducible penile abnormalities present in wild-type mice, implying an unequivocal role for $E R \alpha$ in mediating maldevelopment of the penis.

\section{Acknowledgements}

Authors acknowledge the technical help of Ms Salimata KoneCoulibaly in tissue collection, and Dr John R Kammermann (Auburn University) in radiographs. This research was supported by NIH grants MBRS-5-S06-GM-08091 (to HG) and RCMI-5-G12RR03059 and by USDA grant CSR-EES-ALXTU-CTIF. The authors declare that there is no conflict of interest that would prejudice the impartiality of this scientific work.

\section{References}

Akingbemi BT, Ge R, Rosenfeld CS, Newton LG, Hardy DO, Catterall JF, Lubahn DB, Korach KS \& Hardy MP 2003 Estrogen receptor- $\alpha$ gene deficiency enhances androgen biosynthesis in the mouse Leydig cell. Endocrinology 144 84-93.

Ali SH, O'Donnell AL, Mohamed S, Mousa S \& Dandona P 2004 Overexpression of estrogen receptor alpha in the endometrial carcinoma cell line Ishikawa: inhibition of growth and angiogenic factors. Gynecologic Oncology 95 637-645.

Anderson CA \& Clark RL 1990 External genitalia of the rat: normal development and the histogenesis of $5 \alpha$-reductase inhibitor-induced abnormalities. Teratology 42 483-496.

Atanassova N, McKinnell C, Turner KJ, Walker M, Fisher JS, Morley M, Millar MR, Groome NP \& Sharpe RM 2000 Comparative effects of neonatal exposure of male rats to potent and weak (environmental) estrogens on spermatogenesis at puberty and the relationships to adult testis size and fertility: evidence for stimulatory effects of low estrogen levels. Endocrinology 141 3898-3907.

Bhasin S, Taylor WE, Singh R, Artaza J, Sinha-Hikim I, Jasuja R, Choi H \& Gonzalez-Cadavid NF 2003 The mechanisms of androgen effects on body composition: mesenchymal pluripotent cell as the target of androgen action. Journal of Gerontology 58 1103-1110.

Breedlove SM \& Arnold AP 1983 Hormonal control of a developing neuromuscular system: II. Sensitive periods for the androgeninduced masculanization of the rat spinal nucleus of the bulbocavernosus. Journal of Neuroscience 3 424-432.

Brouwers MM, Feitz WFJ, Roelofs LAJ, Kiemeney LALM, de Gier RPE \& Roeleveld N 2006 Hypospadias: a transgenerational effect of diethylstilbestrol? Human Reproduction 21 666-669.

Cooke PS \& Naaz A 2004 Role of estrogen in adipocyte development and function. Experimental Biology and Medicine 229 1127-1135.

Couse JF \& Korach KS 1999 Estrogen receptor null mice: what have we learned and where will they lead us? Endocrine Review 20 358-417.

Couse JF \& Korach KS 2004 Estrogen receptor- $\alpha$ mediates the developmental effects of neonatal diethylstilbestrol (DES) exposure in the murine reproductive tract. Toxicology 205 55-63.

Couse JF, Dixon D, Yates M, Moore AB, Ma L, Maas R \& Korach KS 2001 Estrogen receptor- $\alpha$ knockout mice exhibit resistance to the developmental effects of neonatal diethylstilbestrol exposure on the female reproductive tract. Developmental Biology 238 224-238.

Crescioli C, Maggi M, Vannelli GB, Ferruzzi P, Granchi S, Mancina R, Muratori M, Forti G, Serio M \& Luconi M 2003 Expression of functional estrogen receptors in human fetal male external genitalia. Journal of Clinical Endocrinology and Metabolism 88 1815-1824.

Delbes G, Levacher C, Duquenne C, Racine C, Pakarinen P \& Habert R 2005 Endogenous estrogens inhibit mouse fetal Leydig cell development via estrogen receptor $\alpha$. Endocrinology $\mathbf{1 4 6}$ 2454-2461.

Dietrich W, Haitel A, Huber JC \& Reiter WJ 2004 Expression of estrogen receptors in human corpus cavernousm and male urethra. Journal of Histochemistry and Cytochemistry 52 355-360.

Eddy EM, Washburn TF, Bunch DO, Goulding EH, Gladen BC, Lubahn DB \& Korach KS 1996 Targeted disruption of the estrogen receptor gene in male mice causes alteration of spermatogenesis and infertility. Endocrinology 137 4796-4805.

El-Gehani F, Zhang FP, Pakarinen P, Rannikko A \& Huhtaniemi I 1998 Gonadotropin-independent regulation of steroidogenesis in the fetal rat testis. Biology of Reproduction 58 116-123.

Fisher JS 2004 Environmental anti-androgens and male reproductive health: focus on phthalates and testicular dysgenesis syndrome. Reproduction 127 305-315.

Fisher CR, Graves KH, Parlow AF \& Simpson ER 1998 Characterization of mice deficient in aromatase (ArKO) because of targeted disruption of the cyp 19 gene. PNAS 95 6965-6970.

Foster PMD \& Harris MW 2005 Changes in androgen-mediated reproductive development in male rat offspring exposure to a single oral dose of flutamide at different gestational ages. Toxicological Sciences 85 1024-1032. 
George FW \& Wilson JD 1994 Sex determination and differentiation. In The Physiology of Reproduction, pp 3-28. Eds E Knobil \& J Neil. New York: Raven Press.

Gill WB, Schumacher GFB, Bibbo M, Straus FH \& Schoenberg HW 1979 Association of diethylstilbestrol exposure in utero with cryptorchidism, testicular hypoplasia and semen abnormalities. Journal of Urology 122 36-39.

Goyal HO, Robateau A, Braden TD, Williams CS, Srivastava KK \& Ali K 2003 Neonatal estrogen exposure of male rats alters reproductive functions at adulthood. Biology of Reproduction 68 2081-2091.

Goyal HO, Braden TD, Williams CS, Dalvi P, Williams JW \& Srivastava KK 2004a Exposure of neonatal male rats induces abnormal morphology of the penis and loss of fertility. Reproductive Toxicology 18 265-274.

Goyal HO, Braden TD, Williams CS, Dalvi P, Mansour MM, Mansour M, Williams JW, Bartol FF, Wiley AA, Birch L et al. 2004b Abnormal morphology of the penis in male rats exposed neonatally to diethylstilbestrol is associated with altered profile of estrogen receptor- $\alpha$ protein, but not of androgen receptor protein: a developmental and immunocytochemical study. Biology of Reproduction 70 284-297.

Goyal HO, Braden TD, Williams CS, Dalvi P, Mansour MM \& Williams JW 2005a Permanent induction of morphological abnormalities in the penis and penile skeletal muscles in adult rats treated neonatally with diethylstilbestrol or estradiol valerate: a dose-response study. Journal of Andrology 26 32-43.

Goyal HO, Braden TD, Williams CS, Dalvi P, Mansour M \& Williams JW 2005b Estrogen-induced abnormal accumulation of fat cells in the rat penis and associated loss of fertility depends upon estrogen exposure during critical period of penile development. Toxicological Sciences 87 242-254.

Gray LE Jr, Ostby J, Furr J, Wolf CJ, Lambright C, Parks L, Veeramachaneni DN, Wilson V, Price M, Hotchkiss A et al. 2001 Effects of environmental antiandrogens on reproductive development in experimental animals. Human Reproduction Update 7 248-264.

Guillette LJ Jr, Gross TS, Masson GR, Matter JM, Percival HF \& Woodward AR 1994 Developmental abnormalities of the gonad and abnormal sex concentrations in juvenile alligators from contaminated and control lakes in Florida. Environmental Health Perspectives 102 680-688.

Guillette LJ, Pickford DB, Crain DA, Rooney AA \& Percival HF 1996 Reduction in penis size and plasma testosterone concentration in juvenile alligators living in a contaminated environment. General and Comparative Endocrinology 101 32-42.

Gupta C 2000 Reproductive malformation of the male offspring following maternal exposure to estrogenic chemicals. Proceedings of the Society for Experimental Biology and Medicine 224 61-68.

Hadi Mansouri S, Siegford JM \& Ulibarri C 2003 Early postnatal response of the spinal nucleus of the bulbocavernosus and target muscles to testosterone in male gerbils. Developmental Brain Research 142 129-139.

Hendry WJ III, Weaver BP, Naccarato TR \& Khan SA 2006 Differential progression of neonatal diethylstilbestrol-induced disruption of the hamster testis and seminal vesicle. Reproductive Toxicology 21 $225-240$.

Hiort O 2000 Neonatal endocrinology of abnormal male sexual differentiation: molecular aspects. Hormone Research $\mathbf{5 3}$ (Suppl 1) $38-41$.

Ho SM, Tang WY, Belmonte de Frausto J \& Prins GS 2006 Developmental exposure to estradiol and bisphenol A increases susceptibility to prostate carcinogenesis and epigenetically regulates phosphodiesterase type 4 variant 4. Cancer Research 66 5624-5632.

Jesmin S, Mowa CN, Matsuda N, Salah-Eldin A-E, Togashi H, Sakuma I, Hattori Y \& Kitabatake A 2002 Evidence for a potential role of estrogen in the penis: detection of estrogen receptor- $\alpha$ and $-\beta$ messenger ribonucleic acid and protein. Endocrinology 143 $4764-4774$.
Jesmin S, Mowa CN, Sakuma I, Matsuda N, Togashi H, Yoshioka M, Hattori Y \& Kitabatake A 2004 Aromatase is abundantly expressed by neonatal rat penis but downregulated in adulthood. Journal of Molecular Endocrinology 33 343-359.

Kim KS, Liu W, Cunha GR, Russell DW, Huang H, Shapiro E \& Baskin LS 2002 Expression of the androgen receptor and 5 alphareductase type 2 in the developing human fetal penis and urethra. Cell Tissue Research 307 145-153.

Kim KS, Torres CR Jr, Yucel S, Raimondo K, Cunha GR \& Baskin LS 2004 Induction of hypospadias in a murine model by maternal exposure to synthetic estrogens. Environmental Research 94 267-275.

Klip H, Verloop J, van Gool JD, Koster ME, Burger CW \& van Leeuwen FE 2002 Hypospadias in sons of women exposed to diethylstilbestrol in utero: a cohort study. Lancet 359 1081-1082.

Klonisch T, Fowler PA \& Hombach-Klonisch S 2004 Molecular and genetic regulation of testis descent and external genitalia development. Developmental Biology 270 1-18.

Markey CM, Wadia PR, Rubin BS, Sonnenschein C \& Soto AM 2005 Long-term effects of fetal exposure to low doses of the xenoestrogen bisphenol-A in the female mouse genital tract. Biology of Reproduction 72 1344-1351.

McKinnell C, Atanassova N, Williams K, Fisher JS, Walker M, Turner KJ, Saunders PTK \& Sharpe RM 2001 Suppression of androgen action and the induction of gross abnormalities of the reproductive tract in male rats treated neonatally with diethylstilbestrol. Journal of Andrology 22 323-338.

McLachlan JA, Newbold RR \& Bullock B 1975 Reproductive tract lesions in male mice exposed prenatally to diethylstilbestrol. Science 190 991-992.

McLachlan JA, Newbold RR, Burow ME \& Li SF 2001 From malformations to molecular mechanisms in the male: three decades of research on endocrine disrupters. APMIS 109 263-272.

Milnes MR, Bermudez DS, Bryan TA, Gunderson MP \& Guillette LJ Jr 2005 Altered neonatal development and endocrine function in Alligator mississippiensis associated with a contaminated environment. Biology of Reproduction 73 1004-1010.

Moon DG, Sung DJ, Kim YS, Cheon J \& Kim JJ 2001 Bisphenol A inhibits penile erection via alteration of histology in the rabbit. International Journal of Impotence Research 13 309-316.

Moon DG, Lee KC, Kim YW, Park HS, Cho HY \& Kim JJ 2004 Effect of TCDD on corpus cavernosum histology and smooth muscle physiology. International Journal of Impotence Research $\mathbf{1 6}$ 224-230.

Mosconi G, Carnevali O, Franzoni MF, Cottone E, Lutz I, Kloas W, Yamamoto K, Kikuyama S \& Polzonetti-Magni AM 2002 Environmental estrogens and reproductive biology in amphibians. General and Comparative Endocrinology 126 125-129.

Mowa CN, Jesmin S \& Miyauchi T 2006 The penis: a new target and source of estrogen in male reproduction. Histology and Histopathology 21 53-67.

Murakami R 1986 Development of the os penis in genital tubercles cultured beneath the renal capsule of adult rats. Journal of Anatomy 149 11-20.

Murakami R 1987 A histological study of the development of the penis of wild-type and androgen-insensitive mice. Journal of Anatomy 153 223-231.

Newbold RR 2004 Lessons learned from perinatal exposure to diethylstilbestrol. Toxicology and Applied Pharmacology 199 142-150.

North K \& Golding J 2000 A maternal vegetarian diet in pregnancy is associated with hypospadias. The ALSPAC Study Team. Avon longitudinal study of pregnancy and childhood. BJU International 85 107-113.

Park TJ, Song KY, Sohn SH \& Lim IK 2002 Marked inhibition of testosterone biosynthesis by hepatotoxin nodularin due to apoptosis of Leydig cells. Molecular Carcinogenesis 34 151-163. 
Prins GS \& Birch L 1995 The developmental pattern of androgen receptor expression in rat prostate lobes is altered after neonatal exposure to estrogen. Endocrinology 136 1303-1314.

Prins GS \& Birch L 1997 Neonatal estrogen exposure up-regulates estrogen receptor expression in the developing and adult rat prostate lobes. Endocrinology 138 1801-1809.

Prins GS, Birch L, Couse JF, Choi I, Katzenellenbogen B \& Korach KS 2001 Estrogen imprinting of the developing prostate gland is mediated through stromal estrogen receptor $\alpha$ : studies with $\alpha$ ERKO and BERKO mice. Cancer Research 61 6089-6097.

Putz O, Schwartz CB, LeBlanc GA, Cooper RL \& Prins GS 2001 Neonatal low- and high-dose exposure to estradiol benzoate in the male rat: II. Effects on male puberty and the male reproductive tract. Biology of Reproduction 65 1506-1517.

Rajfer J, Namkung PC \& Petra PH 1980 Identification, partial characterization and age-related changes of a cytoplasmic androgen receptor in the rat penis. Journal of Steroid Biochemistry 13 1489-1492.

Regadera J, Martinez-Garcia F, Paniagua R \& Nistal M 1999 Androgen insensitivity syndrome. An immunohistochemical, ultrastructural, and morphometric study. Archives of Pathology \& Laboratory Medicine 123 225-234.

Rivas A, McKinnell C, Fisher JS, Atanassova N, Williams K \& Sharpe RM 2003 Neonatal coadministration of testosterone with diethylstilbestrol prevents induction of most reproductive tract abnormalities in male rats. Journal of Andrology 24 557-567.

vom Saal FS \& Hughes C 2005 An extensive new literature concerning low-dose effects of bisphenol A shows the need for new risk assessment. Environmental Health Perspectives 113 926-933.

vom Saal FS, Timms BG, Montano MM, Palanza P, Thayer KA, Nagel SC, Dhar MD, Ganjam VK, Parmigiani S \& Welshons WV 1997 Prostate enlargement in mice due to fetal exposure to low doses of estradiol or diethylstilbestrol and opposite effects at high doses. PNAS 94 2056-2061.

Safe SH, Pallaroni L, Yoon K, Gaido K, Ross S, Saville B \& McDonnell D 2001 Toxicology of environmental estrogens. Reproduction, Fertility, and Development 13 307-315.

Sato T, Chiba A, Hayashi S, Okamura H, Okamura H, Ohta Y, Takasugi N \& Iguchi T 1994 Induction of estrogen receptor and cell division in genital tracts of male mice by neonatal exposure to diethylstilbestrol. Reproductive Toxicology 8 145-153.

Schultheiss D, Badalyan R, Pilatz A, Gabouev AI, Schlote N, Wefer J, von Wasielewski R, Mertsching H, Sohn M, Stief CG et al. 2003 Androgen and estrogen receptors in the human corpus cavernosum penis: immunohistochemical and cell culture results. World Journal of Urology 21 320-324.

Sharpe RM, Atanassova N, McKinnell C, Parte P, Turner KJ, Fisher JS, Kerr JB, Groome NP, Macpherson S, Millar MR et al. 1998 Abnormalities in functional development of Sertoli cell in rats treated neonatally with diethylstilbestrol: a possible role for estrogens in Sertoli cell development. Biology of Reproduction 59 1084-1094.

Singh R, Artaza JN, Taylor WE, Gonzalez-Cadavid NF \& Bhasin S 2003 Androgens stimulate myogenic differentiation and inhibit adipogenesis in $\mathrm{C} 3 \mathrm{H} 10 \mathrm{~T} 1 / 2$ pluripotent cells through an androgen receptormediated pathway. Endocrinology 144 5081-5088.

Srilatha B \& Adaikan PG 2004 Estrogen and phytoestrogen predispose to erectile dysfunction: Do ER- $\alpha$ and ER- $\beta$ in the cavernosum play a role? Urology 63 382-386.

Storgaard L, Bonde JP \& Olsen J 2006 Male reproductive disorders in humans and perinatal indicators of estrogen exposure. A review of published epidemiological studies. Reproductive Toxicology 21 4-15.
Sultan C, Paris F, Terouanne B, Balaguer P, Georget V, Poujol N, Jeandel C, Lumbroso S \& Nicolas J-C 2001 Disorders linked to insufficient androgen action in male children. Human Reproduction Update 7 314-322.

Swan SH 2000 Intrauterine exposure to diethylstilbestrol: long-term effects in humans. APMIS $\mathbf{1 0 8} 793-804$.

Takane KK, George FW \& Wilson JD 1990 Androgen receptor of rat penis is down regulated by androgen. American Journal of Physiology 21 E46-E50.

Tekmal RR, Liu Y-G, Nair HB, Jones J, Perla RP, Lubahn DB, Korach KS \& Kirma N 2005 Estrogen receptor alpha is required for mammary development and the induction of mammary hyperplasia and epigenetic alterations in the aromatase transgenic mice. Journal of Steroid Biochemistry and Molecular Biology 95 9-15.

Toppari J, Larsen JC, Christiansen P, Giwercman A, Grandjean P, Guillette LJ Jr, Jegou B, Jensen TK, Jouannet P, Keiding N et al. 1996 Male reproductive health and environmental xenoestrogens. Environmental Health Perspectives 104 741-803.

Traish AM, Toselli P, Jeong SJ \& Kim NN 2005 Adipocyte accumulation in penile corpus cavernosum of the orchiectomized rabbit: a potential mechanism for veno-occlusive dysfunction in androgen deficiency. Journal of Andrology 26 242-248.

Traish AM \& Kim N 2005 Weapons of penile smooth muscle destruction: androgen deficiency promotes accumulation of adipocytes in the corpus cavernosum. Aging Male 8 141-146.

Vidaeff AC \& Sever LE 2005 In utero exposure to environmental estrogens and male reproductive health: a systematic review of biological and epidemiologic evidence. Reproductive Toxicology 20 5-20.

Ward IL \& Weisz J 1984 Differential effects of maternal stress on circulating levels of corticosterone, progesterone, and testosterone in male and female rat fetuses and their mothers. Endocrinology $\mathbf{1 1 4}$ 1635-1644.

Wiener JS, Teague JL, Roth DR, Gonzales ET Jr \& Lamb DJ 1997 Molecular biology and function of the androgen receptor in genital development. Journal of Urology 157 1377-1386.

Williams K, Fisher JS, Turner KJ, McKinnell C, Saunders PTK \& Sharpe RM 2001 Relationship between expression of sex steroid receptors and structure of the seminal vesicles after neonatal treatment of rats with potent or weak estrogens. Environmental Health Perspectives 109 21-29.

Williams-Ashman HG \& Reddi AH 1991 Differentiation of mesenchymal tissues during phallic morphogenesis with emphasis on the os penis: roles of androgens and other regulatory agents. Journal of Steroid Biochemistry and Molecular Biology 39 873-881.

Woodham C, Birch L \& Prins GS 2003 Neonatal estrogen down-regulates prostatic androgen receptor through a proteosome-mediated protein degradation pathway. Endocrinology 144 4841-4850.

Yamashita S, Newbold RR, McLachlan JA \& Korach KS 1990 The role of the estrogen receptor in uterine epithelial proliferation and cytodifferentiation in neonatal mice. Endocrinology 127 2456-2463.

Zadina JE, Dunlap JL \& Gerall AA 1979 Modifications induced by neonatal steroids in reproductive organs and behavior of male rats. Journal of Comparative and Physiological Psychology 93 314-322.

Received 14 November 2006

First decision 21 December 2006

Revised manuscript received 30 January 2007

Accepted 12 February 2007 